\title{
PENGARUH EKSTRAK JAHE MERAH (Zingiber officinale rosc var.rubrum) TERHADAP KADAR KOLESTEROL LDL DAN HDL PADA MENCIT DIET TINGGI LEMAK
}

\author{
Achmad Hilman Fahmy', Abraham ahmad ali Firdaus ${ }^{2,3}$, Ainul Rofiq ${ }^{4,5}$, Hotimah Masdan Salim*, \\ David Sajid Muhammad ${ }^{1}$
}

1. Fakultas Kedokteran, Universitas Nahdlatul Ulama Surabaya

2. Departemen Kardiologi, Fakultas Kedokteran, Universitas Nahdlatul Ulama Surabaya

3. Departemen Kardiologi, Rumah Sakit Islam Jemursari, Surabaya

4. Depatemen Anestesiologi, Fakultas Kedokteran, Universitas Nahdlatul Ulama Surabaya

5. Departemen Anestesiologi, Rumah Sakit Islam Jemursari, Surabaya

6. Departemen Biokimia Kedokteran, Fakultas Kedokteran, Universitas Nahdlatul Ulama Surabaya Correspondent author; dr.hotimah@unusa.ac.id

\begin{abstract}
Abstrak
Dislipidemia merupakan gangguan metabolisme lipoprotein yang berpengaruh terhadap fraksi lipid dalam darah yang dapat ditandai dengan peningkatan kadar kolesterol total, trigliserida, LDL dan penurunan HDL (Muntafiah, A., 2017). Jahe merah mengandung flavonoid yang bertindak sebagai reactive oxidative stress dalam menghambat peningkatan LDL dan Penurunan HDL (Stoilova et al., 2007). Tujuan penelitian ini adalah Mengetahui pengaruh pemberian ekstrak jahe merah terhadap kadar kolesterol LDL dan HDL pada mencit jantan hiperkolesterolemia. Penelitian ini merupakan penelitian eksperimental dengan rancangan penelitian Post Test Only Controlled Group Design. Penelitian ini menggunakan 30 ekor mencit yang diberi makanan tinggi lemak selama 28hari dan diberikan terapi ekstrak jahe merah selama 14 hari dengan dosis 500, 1000, 1500 mg/KgBB. Hasil penelitian akan diproses menggunakan uji Kruskal-Wallis dan uji Mann-Whitney. Berdasarkan hasil penelitian menunjukkan bahwa terdapat signifikansi ekstrak jahe merah terhadap kadar LDL dan HDL mencit pada dosis 500, 1000, $1500 \mathrm{mg} / \mathrm{KgBB}$ dengan nilai signifikansi $(p<0,05)$. Terdapat pengaruh Ekstrak jahe merah dalam menurunkan LDL dan meningkatkan HDL terutama dalam dosis $1000 \mathrm{mg} / \mathrm{KgBB}$.
\end{abstract}

Keyword: Dislipidemia; LDL; HDL; Jahe

merah (Zingiber officinale var. rubrum).

\section{Pendahuluan}

Dislipidemia merupakan gangguan metabolisme lipoprotein yang berpengaruh terhadap fraksi lipid dalam darah yang dapat ditandai dengan peningkatan kadar kolesterol total, trigliserida, Low Density Lipid (LDL) dan penurunan High Density Lipid (HDL). Keadaan ini dapat menyebabkan risiko terjadinya aterosklerosis yang dapat berkembang menjadi penyakit stroke dan kematian (Muntafiah, A., 2017).

Kandungan kimia jahe merah (Zingiber officinale var. rubrum) adalah senyawa volatile dan non volatile. Senyawa volatile terdiri dari berbagai senyawa terpenoid, sedangkan senyawa non volatile terdiri dari gingerol, shogaol, paradol, zingerone dan turunan mereka serta senyawa-senyawa flavonoid dan polifenol yang mempunyai efek antioksidan dapat mencegah adanya radikal bebas dalam tubuh, kandungan gingerol dalam jahe memiliki efek hipokolesterol, anti- aterogenik serta penekanan aktivitas enzim HMG-KoA reduktase sehingga dapat mengurangi kolesterol total (Stoilova et al., 2007). 
Berdasarkan penelitian yang telah dilakukan oleh Hapsari, H Putri. Rahayuningsih (2015), pada 34 wanita yang mengalami dislipidemia dengan kadar kolesterol LDL lebih dari 100mg/dl-159mg/dl menunjukkan hasil bahwasannya ekstrak jahe merah dapat menurunkan kadar kolesterol LDL sebesar 12,75\%. Dari ulasan atau penelitian tersebut peneliti tertarik untuk melakukan penelitian lebih lanjut tentang "Pengaruh Ekstrak Jahe Merah (Zingiber Officinale var rubrum) Terhadap Kadar Kolesterol LDL dan HDL pada mencit (mus musculus) Hiperkolesterolemia”.

\section{Metode}

Metode penelitian yang digunakan dalam penelitian ini adalah penelitian eksperimental laboratorium murni in vivo dengan rancangan acak lengkap. Penelitian dilakukan selama 28 hari dan di akhir masa perlakuan dilakukan pengukuran kadar HDL dan LDL.

\section{Hewan Coba}

Mencit musmusculus usia 8 minggu dengan berat badan 20-30 gram. Dikelompokkan menjadi 5 kelompok secara acak. Kontrol negative (tanpa perlakuan), Kontrol positif (Diet tinggi lemak), Perlakuan 1 (Diet tinggi lemak+Ekstrak jahe merah dosis 1), perlakuan 2 (Diet tinggi lemak+Ekstrak jahe merah dosis 2), Perlakuan 3 (Diet tinggi lemak+Ekstrak jahe merah dosis 3). Setelah diberikan perlakuan selama 28 hari dilakukan pembedahan dan pemeriksaan laboratorium darah untuk mengukur kadar HDL dan LDL di laboratoium patologi klinik RSI Jemursari.

\section{Pembuatan Diet Tinggi lemak}

Pembuatan pakan hiperkolesterolemia menggunakan dengan cara pemberian pakan yang ditambah kolesterol 2\%, minyak babi $5 \%$, dan asam kolat $0,2 \%$.

\section{Ekstrak Jahe merah Zingiber officinale rosc var.rubrum}

Pembuatan ekstrak menggunakan metode maserasi, metode maserasi yang dipilih adalah menggunakan larutan etanol 96\%, penggunaan larutan etanol $96 \%$ bertujuan agar zat aktif dapat tersari secara maksimal dan sesuai dengan sifat zat aktif tersebut serta untuk menghasilkan ekstrak yang kental (murni). Konsentrasi ekstrak jahe merah tiap kelompok adalah perlakuan 1 (500mg/KgBB), Perlakuan 2 (1000 mg/KgBB), Perlakuan 3 (1500 mg/KgBB).

\section{Analisa Data}

Data yang diperoleh dari hasil penelitian dianalisis menggunakan uji KolmogorovSmirnov dan uji Levene. Kemudian dilakukan uji statistik parametrik dengan One-Way ANOVA kemudian dilanjutkan dengan uji Least Significant Difference (LSD) dengan derajat kemaknaan $\mathrm{p}<0,05 \quad(\alpha=95 \%)$. Kemudian dilanjutkan dengan uji statistik non parametrik Kruskal-Wallis dengan derajat kemaknaan 95\% $(\mathrm{p}<0,05)$, dan dilanjutkan dengan uji MannWhitney dengan derajat kemaknaan $95 \%$ $(\mathrm{p}<0,05)$.

Hasil

Setelah diberikan perlakuan selama 28 hari dilakukan pengambilan darah untuk menilai kadar HDL dan LDL. Didapatkan hasil bahwa pemberian diet tinggi lemak menurunkan kadar HDL di dalam darah. Akan tetapi pemerian ekstrak jahe merah meningkatkan kadar HDL, dimana pada $\mathrm{P} 1$ dengan dosis $500 \mathrm{mg} / \mathrm{kg}$ BB dan $\mathrm{P} 2$ dengan dosis $1000 \mathrm{mg} / \mathrm{kgBB}$ tidak didapatkan kenaikan yang signifikan dibandingkan dengan kelompok kontrol positif. Namun, pada pemerian ekstrak jahe merah pada dosis $1500 \mathrm{mg} / \mathrm{kgBB}$ meningkatkan kadar HDL secara signifikan $(\mathrm{P}<0.05)$.di bandingkan dengan kelompok kontrol positif. 


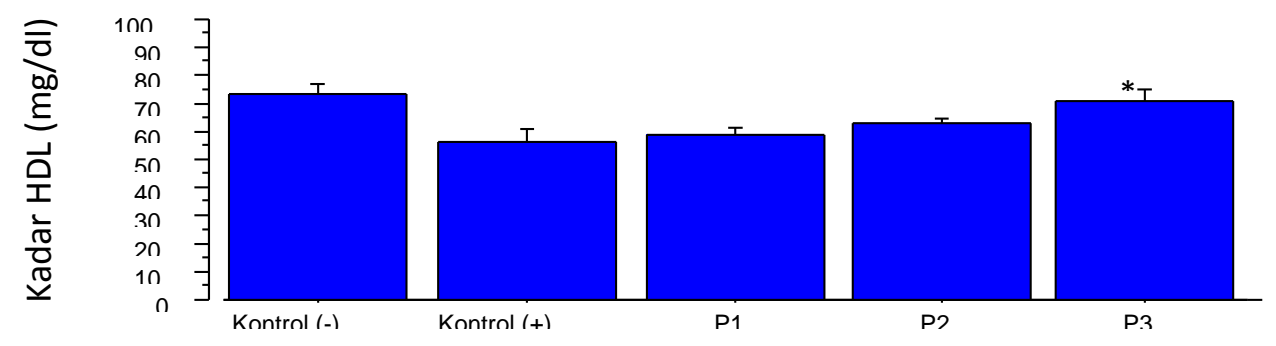

Figure.1 Kadar HDL di dalam darah. Kontrol (-); tanpa perlakuan, kontrol (+); diet tinggi lemak, P1; perlakuan dengan dosis 500mg/kgBB, P2; Perlakuan dengan dosis $100 \mathrm{mg} / \mathrm{kgBB}$, P3; Perlakuan dengan dosis $1500 \mathrm{mg} / \mathrm{kgBB} .{ }^{*} ; \mathrm{P}<0.05$

Untuk mengetahui efektifitas kadar kolesterol, dilakukan pemeriksaan kadar LDL di dalam darah. Penelitian ini menunjukkan bahwa pemeberian diet tinggi lemak meningkatkan kadar kolesterol-LDL secara signifikan $(\mathrm{P}<0.001)$ dibandingkan dengan kelompok kontrol negatif. Pada penelitian ini pemberian ekstrak jahe merah efektif menurunkan kadar kolesterol-LDL secara signifikan sesuai dengan semakin meningkatnya dosis yang diberikan $(\mathrm{P}<0,05)$. Akan tetapi efektifitas ekstrak jahe merah ini bernilai kut pada pemberian dengan dosis maksimal 1500mg/kg/BB dengan $\mathrm{P}<0.001$.

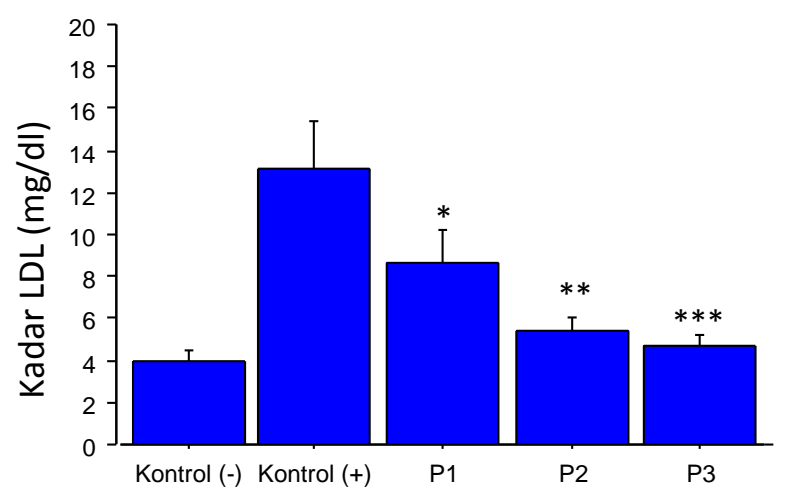

Figure.2 Kadar HDL di dalam darah. Kontrol (-); tanpa perlakuan, kontrol (+); diet tinggi lemak, P1; perlakuan dengan dosis 500mg/kgBB, P2; Perlakuan dengan dosis 100mg/kgBB, P3; Perlakuan dengan dosis $1500 \mathrm{mg} / \mathrm{kgBB} . * ; \mathrm{P}<0.05, * * ; \mathrm{P}<0.01$, ***; $\mathrm{P}<0.001$

\section{Pembahasan}

Dari hasil penelitian yang sudah dilakukan menunjukan bahwa ekstrak etanol jahe merah efektif terhadap penurunan kadar kolestrol LDL mencit.. Ekstrak etanol jahe merah efektif terhadap penurunan kadar kolestrol LDL mencit karena mengandung flavonoid yang berupa gingerol, dimana gingerol merupakan antioksidan yang memiliki efek penekanan aktivitas enzim HMGKoA reduktase sehingga dapat mengurangi/menurunkan kadar LDL. Hasil ini sesuai dengan penelitian sebelumnya yang sudah dilakukan oleh Riesanti, dkk (2012) dimana kandungan flavonoid pada air benalu mangga efektif terhadap penurunan kadar LDL darah 
mencit.

Adapun mekanisme peningkatan kadar LDL pada penelitian ini terjadi karena pemberian diet tinggi lemak pada mencit yang menyebabkan kadar kolestrol meningkat (Jim, 2014). Hiperkolestrol menyebabkan Asam lemak di hepar mengalami peningkatan dan diubah menjadi asetil-CoA. Proses biosintesis lemak di hepar dimulai dari perubahan asetil-CoA menjadi HMGCoA. HMG-CoA akan diubah menjadi mevalonat oleh HMG-CoA reductase. Setelah melalui beberapa proses, kemudian hasil akhir yang disintesis yaitu kolesterol dalam jumlah yang banyak (Berg, J. M., 2010; Anindito, 2014). Beberapa kolesterol ada yang berperan sebagai salah satu bahan dalam pembentukan asam empedu dan ada juga yang mengalami esterifikasi oleh enzim Acyl-CoA cholesterol acyl transferase menjadi kolesterol ester yang bersama Apo-B100 dan komponen VLDL lainnya membentuk VLDL. Sintesis VLDL ini dimediasi oleh enzim microsomal triglyceride transfer protein (MTP). Peningkatan VLDL yang terbentuk akan dikonversi menjadi IDL yang kemudian dikonversi menjadi LDL (Anindito, 2014).

Pada penelitian sebelumnya yang dilakuakan oleh R. Sari, (2014) bahwa kandungan flavonoid dalam jahe merah mampu mencegah terbentuknya reactive oxidative stress dalam tubuh dengan mekanisme menekan aktifitas enzim HMG-KoA reduktase pada sintesis kolesterol sehingga dapat mencegah proses oksidasi LDL yang berlebihan. Pada penelitian ini, kelompok perlakuan 2 (Dosis Sedang $1000 \mathrm{mg} / \mathrm{KgBB}$ ) efektif dalam menurunkan kadar LDL mencit.

Dari hasil penelitian yang sudah dilakukan menunjukan bahwa ekstrak etanol jahe merah efektif terhadap peningkatan kadar kolestrol HDL mencit yang diberikan diet tinggi lemak. Ekstrak etanol jahe merah mengandung flavonoid yang efektif terhadap peningkatan kadar HDL karena bersifat antioksidan. Dimana antioksidan akan meningkatkan kadar HDL dengan cara meningkatkan mRNA Apo A1 hati (Brown, 1994). Hasil ini sesuai dengan penelitian yang sudah dilakukan oleh Riesanti, dkk (2012) bahwa kandungan flavonoid pada air benalu mangga efektif terhadap peningkatan kadar HDL darah mencit.
Pada kondisi hiperkolesterolemia akan menyebabkan peningkatan LDL dan penurunan HDL, hal tersebut disebabkan karenan penumpukan kolesterol berlebih dengan diikuti aktivitas radikal bebas yang menyebabkan adanya kerusakan oksidatif pada beberapa jaringan (Jung, H.A., 2003). Kadar kolesterol yang tinggi dalam darah menyebabkan VLDL membentuk LDL, akibatnya LDL dalam darah meningkat. Kadar LDL yang terus meningkat membuat HDL tertekan dan tidak bisa membuang kelebihan kolesterol yang ada dalam darah, sehingga keadaan HDL menurun (Sargowo, 2001)

Pada penelitian sebelumnya yang dilakukan oleh Fitriarini \& Rahayuningsih, (2014) bahwa flavonoid dalam meningkatkan kadar HDL dengan cara meningkatkan produksi apo A1 dan menghambat sekresi apo B100. Penghambatan sekresi apo B100 ke intestinum menyebabkan jumlah apo-B menurun. Apo B merupakan pembentuk VLDL dan LDL. Kadar kolesterol HDL mengalami peningkatan secara tidak tangsung yang disebabkan karena penurunan kadar VLDL, LDL dan trigliserida serta meningkatnya produksi apo AI dan apo AII.

\section{Kesimpulan}

Berdasarkan hasil dari penelitian ini dapat disimpulkan bahwa: Ekstrak etanol jahe merah dosis $1000 \mathrm{mg} / \mathrm{KgBB}$ efektif dalam menurunkan kadar LDL darah mencit dan pada Ekstrak etanol jahe merah dosis $1000 \mathrm{mg} / \mathrm{KgBB}$ efektif dalam meningkatkan kadar HDL darah mencit.

\section{Ucapan Terima Kasih:}

Penulis mengucapkan terima kasih kepada Abraham ahmad ali Firdaus, dr., Sp.JP, dr. Ainul Rofiq, Sp.An-KIC, Hotimah Masdan Salim, dr., P.hD dan Fakultas Kedokteran Universitas Nahdlatul Ulama Surabaya.

Anindito, A. A. (2014). Pengaruh Pemberian Ekstrak Etanol 95\% Cabe Jawa (PIper retrofractum Vahl.) terhadap Kadar Kolesterol Total dan Trigliserida pada Tikus Putih Jantan (Rattus novergicus) Galur Sprague Dawley yang Diberikan 
Diet Tinggi Lemak. In Skripsi.

Berg, J. M., Tymoczko, J. L \& Stryer, L. (2010). Biochemistry 7th edn. W.H Freeman and Company.

Brown, M. S. \& G. (1994). The hyperlipoprotein and orther disorders of lipid metabolism. In Harrison's Principle of Internal Medicine. 13th edn. Mc Graw Hill Medical.

Fitriarini, S., \& Rahayuningsih, H. M. (2014). PERBEDAAN PENGARUH ANTARA EKSTRAK DAN REBUSAN DAUN SALAM (Eugenia polyantha) DALAM PENCEGAHAN PENURUNAN KADAR KOLESTEROL HDL PADA TIKUS SPRAGUE DAWLEY. Journal of Nutrition College, 3(1), 184-191. https://doi.org/10.14710/jnc.v3i1.4557

Hapsari, H Putri. Rahayuningsih, H. M. (2015). Pengaruh Pemberian Jahe Merah Terhadap Kadar Kolesterol LDL Wanita Dislipidemia. 4(5), 365-371.

Jim, E. L. (2014). Metabolisme Lipoprotein. Jurnal Biomedik (Jbm), 5(3). https://doi.org/10.35790/jbm.5.3.2013.433 5

Jung, H.A., Jung, M.J., Kim, J.Y., Chung, H.Y., Choi, J. S. (2003). Inhibitory activity of flavonoids from Prunus davidiana and other flavonoids on total ROS and hydroxyl radical generation. Arch. Pharm. Res, 26, 809-815.

Muntafiah, A., Yuliantim, D., Cahyaningtyas, A. H \& Damayanti, H. I. (2017). Pengaruh
Ekstrak Jahe Merah (Zingiber officinale) Dan Madu Terhadap Kadar Kolesterol Total Tikus Model Diabetes Melitus. Scripta Biologica, 4(1), 1-3.

R. Sari, and H. R. (2014). PENGARUH PEMBERIAN JAHE MERAH (Zingiber Officinale Var Rubrum) TERHADAP KADAR KOLESTEROL TOTAL WANITA DISLIPIDEMIA. Ournal of Nutrition College, 3(4), 798-806. https://doi.org/https://doi.org/10.14710/jnc .v3i4.6883

Riesanti, D.G., Padaga, M.C., \& H. (2012). Kadar HDL, Kadar LDL dan Gambaran Histopatologi Aorta pada Hewan Model Tikus (Rattus norvegicus) Hiperkolesterolemia dengan Terapi Ekstrak Air Benalu Mangga (Dendrophthoe pentandra). Fakultas Kedokteran Hewan Universitas Brawijaya. Sargowo, D. (2001). Peranan Kadar Trigliserida Dan Lippoprotein Sebagai Faktor Resiko Penyakit Jantung Koroner. Jurnal Saintika, 13 (2).

Stoilova, I., Krastanov, A., Stoyanova, A., Denev, P., \& Gargova, S. (2007). Antioxidant activity of a ginger extract (Zingiber officinale). Food Chemistry, 102(3), 764-770. https://doi.org/10.1016/j.foodchem.2006.0 6.023 